\title{
The Impacts of Forced Migration on Regional Economies: The Case of Syrian Refugees in Turkey
}

\author{
Cengiz Bahcekapili ${ }^{1} \&$ Buket Cetin $^{1}$ \\ ${ }^{1}$ Faculty of Economics, Department of Economics, Marmara University, Istanbul, Turkey \\ Correspondence: Cengiz Bahcekapili, Faculty of Economics, Department of Economics, Marmara University \\ Goztepe Campus, 34722, Istanbul, Turkey. E-mail: cbahcekapili@ marmara.edu.tr
}

Received: July 12, 2015

Accepted: July 22, 2015

Online Published: August 25, 2015

doi: 10.5539/ibr.v8n9p1

URL: http://dx.doi.org/10.5539/ibr.v8n9p1

\begin{abstract}
The civil war in Syria which began in 2010 has led to a significant migration wave in the region. Many countries neighboring Syria, especially Turkey, have received a large number of immigrants in their lands. Initially thought to be temporary, this necessary move has become a significant economic, political and social problem with the intensification of the internal conflict in Syria. According to official figures, the number of Syrian refugees in Turkey reached 1.7 million in 2015. A significant proportion of refugees live in camps near the Syrian border and in large cities and towns close to the camps. Such humanitarian crises have a number of negative effects not only on the immigrants themselves but also on the host countries. The main objective of the study is to discuss the economic impacts of the Syrian immigrant crisis since 2011 on Southeastern Anatolia region, which is intensely populated by the migration and in Turkey in general. The effects of migration on unemployment, prices, internal migration and regional foreign trade will be examined.
\end{abstract}

Keywords: regional migration, regional labor markets, regional economic activity: growth, development, environmental issues, and changes, trade and labor market interactions

\section{Introduction}

Every year thousands of people are forced to leave their own country with the hope of finding a safer place. According to the UN Refugee Agency (UNHCR)'s official figures, the number of refugees and internally displaced people in the world was 5.7 million in 1980 and 9 million in 2005 and reached 231 million by the end of 2013. Visitors are not included in the figures. The civil war in Syria which began in 2010 has led to a significant migration wave in the region. Many countries neighboring Syria, especially Turkey, have received a large number of immigrants in their lands. Initially thought to be temporary, this necessary move has become a significant economic, political and social problem with the intensification of the internal conflict in Syria. According to official figures, the number of Syrian refugees in Turkey reached 1.7 million in 2015. Initially the Turkish government called the immigrants "visitors", but as their number increased, it became an obligation to grant them temporary protection status dictated by the European Union's 2001 regulations. A significant proportion of refugees live in camps near the Syrian border and in large cities and towns close to the camps. Such humanitarian crises have a number of negative effects not only on the immigrants themselves but also on the host countries.

Migration movements have always been a cause of tension and debate between the proponents of the open door policy and those who are wary of the social and economic impacts of immigration. Standard economic theory suggests that in principle immigration, similarly to free trade, would create surplus which would be redistributed and allow all the natives be better off (Mundell, 1957). Nevertheless, it is known that natives are not generally sympathetic to immigration and immigrants. The most basic reason behind this is that such models do not contain changes and interactions occurring among factors such as host country's ethnic composition, culture and religion. These factors which are outside the conventional economic effects of immigration are called compositional amenities. Card Dustmann and Preston (2009), in their study based on the 2002 European Social Survey, conclude that the native population cares more about the compositional effects than the conventional economic effects. It is a common opinion that the native population is against immigration often due to such effects.

History is strewn with different sizes and types of migration. The movement of immigrants within the host 
country-their gathering in a particular region as a result of necessity or of solidarity or their dispersion within the host country has different consequences. The aggregation of Syrian refugees in southeast Anatolia creates an advantage to study regional economic impacts. It can be said that utility analysis is often ignored when performing a cost analysis. However, in case of migration human capital mobility becomes a matter of significance. Human capital can have various effects on regional growth and development depending on gender, age, education and personal qualities. However, as forced migration is disastrous mostly for low-income and uneducated segments of a society, members of the host country may react to the aids and policies aimed at the immigrants later on. The most fundamental reason behind such conflicts is that naturally occurring problems are not foreseen and appropriate regulations are not made.

Table 1. Biggest refugee flows after the Second World War

\begin{tabular}{lll}
\hline \multicolumn{1}{c}{ Years } & \multicolumn{1}{c}{ Refugee Flows } & Number of Refugees \\
\hline $1945-1950$ & From East Europe to West Germany after Second World War & 12 million \\
1940 s & Migration from East Finland to West Finland during Second World War & \\
$1993-1994$ & From Burundi to Tanzania & 300 thousand \\
1994 & From Rwanda to Tanzania & 250 thousand \\
$1992-1995$ & From Bosnia-Herzegovina to neighboring countries & 1.3 million \\
2011-present & From Syria to neighboring countries (Turkey, Iraq, Lebanon, Jordan) & 3.9 million \\
\hline
\end{tabular}

Source: Braun and Mahmoud (2014), Sarmivaki,Uusitalo, Janti (2010), Alix-Garcia and Saah (2009), Kondylis (2008) and UNHCR.

World history has witnessed dramatic migration movements due to wars and domestic conflicts. 12 million Germans migrating from Eastern Europe to Western Europe after the Second World War and 430 thousand people migrating from Eastern Finland to Western Finland with the invasion of Russia during the war are among the important migration movements. In 1993-1994, 550 thousand people had to migrate to Tanzania due to civil war in Burundi and Rwanda (Table 1). Between 1992 and 1995 during the Bosnia and Herzegovina war, 1.3 million people migrated to neighboring countries while 25 thousand of them took refuge in Turkey. The internal conflicts in Syria after 2011 led to the largest migration movement in recent history: of 3.9 million Syrians, 1.7 million immigrated to Turkey, 1.2 million to Lebanon, 626 thousand to Jordan, 244 thousand to Iraq and 133 thousand to Egypt (Table 3).

Table 2. Biggest refugee flows to turkey after 1923

\begin{tabular}{clc}
\hline Years & \multicolumn{1}{c}{ Refugee Flows } & Number of Refugees \\
\hline $1923-1950$ & Bulgaria, Greece, Yugoslavia, Romania & 850 thousand \\
$1950-1970$ & Bulgaria, Greece, Yugoslavia, Romania & 372 thousand \\
$1971-1986$ & Bulgaria, Yugoslavia, Afghanistan & 127 thousand \\
1988 & Iran, Iraq & 51 thousand \\
1989 & Bulgaria & 300 thousand \\
1991 & Iraq & 460 thousand \\
$1992-1995$ & Bosnia-Herzegovina & 25 thousand \\
$2011-$ present & Syria & 1.7 million \\
\hline
\end{tabular}

Source: Tekeli (1990) and Kirişçi (1999).

With over 1.7 million people, the Syrian immigration is the largest one in the history of the Turkish Republic. Among other significant migration movements are over one million immigrants coming from Bulgaria, Greece, Yugoslavia and Romania between 1923 and 1970 as a result of the Balkan population exchange, 460 thousand people coming from Iraq following the 1991 Gulf War, 300 thousand people coming from Bulgaria in 1989 and 25 thousand refugees escaping the Bosnia and Herzegovina war (Table 2). 
Table 3. Syrian refugee population in neighboring countries

\begin{tabular}{lr}
\hline Country & Population \\
\hline Turkey & 1718147 \\
Lebanon & 1187407 \\
Jordan & 626357 \\
Iraq & 244731 \\
Egypt & 133516 \\
Other & 24055 \\
Total* & 3934213 \\
\hline
\end{tabular}

*April 2015

Source: http://data.unhcr.org/syrianrefugees/.

According to UNHCR data as of April 2015 the number of Syrian refugees in Turkey has reached 1 million 758 thousand, which accounts for $2.3 \%$ of Turkey's population. The striking number of Syrian refugees makes it mandatory to discuss the matter from a humanitarian, political, social and sociological perspective.

The main objective of the study is to discuss the economic impacts of the Syrian immigrant crisis since 2011 on Southeastern Anatolia region, which is intensely populated by the migration and in Turkey in general. The effects of migration on unemployment, prices, internal migration and regional foreign trade will be examined. Studies on migration usually focus on the adverse effects of migration on regional or urban economy but ignore the transfer of human and material or financial assets or the existence of the networks that make it possible to reach such assets.

The second part of the study includes literature review while the third part explains data and methodology. The fourth part presents findings on the economic effects of immigration and the final part evaluates the results.

\section{Literature Review}

Studies on the emigration to Germany after the Second World War and the Tanzania immigration that took place in 1993-1994 seem to prevail the literature. Among the most widely discussed topics are the effects of immigration on labor markets, prices, national income and welfare.

One of the world's most important historic immigration happened in Germany after the Second World War. Around 8.5 million Germans living in the Soviet Union, Poland and Yugoslavia until 1950 were expelled and flocked West Germany. The expellees' ratio to the population in 1950 was 16\%. Investigating the employment impact of this migration, Braun and Mahmoud (2014) found that a short-lived is displacement effect was experienced in the labor market, which however decreased rapidly in time. The most important feature that distinguished this example from other large movements of forced migration is that the expellees possessed almost the same skills and the same ethnic origin with the natives. When there is a difference between the skills of immigrant workers and native workers, the effects of immigration on the labor market can vary. In their model, Dustmann, Glitz and Frattini (2008) show that wages would fall for low-skilled work group in the short term and native workers would not choose to work at low wages and opt to stay unemployed in a model where human capital comes in different levels and capital supply is not fully flexible.

Card's (1990) study that investigates the effects of the $7 \%$ increase in the labor force caused by immigration to Miami concludes that immigration has no impact on unemployment and wages. In a more recent study, Cortes (2005) finds that unskilled labor-intensive immigrants lower the wages in their segment.

One of the issues related to migration that is rarely investigated is the effects on the growth of per capita income. General economic characteristics of the host country together with the type of the migration and the qualifications of the immigrants can diversify the effects of migration on income. For example, the massive migration from Europe to the US in the early 20th century caused a great positive impact on the internal market and the return to Germany after the Second World War and the intensive migration to Israel also had an effect on economic growth (Friedberg \& Hunt, 1995).

One of the theoretical analyses of growth by migration was performed by Friedberg and Hunter (1995). By modifying Solow's growth model, they conclude that different levels of immigrant human capital may have different effects on growth. If the immigrants' level human capital is low, on the one hand they will increase the rate of population growth and on the other hand they will slow down the growth in per capita income due to their low potential to create added value. Also, if the immigrants' human capital level is higher than the native 
population's, the growth rate will increase. In the same study, the authors also discuss the theoretical effects of migration in an economy which works on conditions laid out by Brezis and Krugman's increasing returns to scale theory and where there is free trade, labor movement (migration) and the chance to borrow on world interest rates. Under these assumptions when migration takes place the growth rate for the host country will be bigger than the normal rate. This will result in increased return on capital and increased wages. In this model, high human capital will require high wages and the total demand for labor in the host country will show a positively sloped curve (Friedberg \& Hunt, 1995).

Another effect of migrant labor qualifications can be seen in the composition of the production of host country's economy. Falling wages for unskilled labor may divert production to labor intensive sectors. This can create negative effects on the long-term development of technology. Because employment would aggregate in low-wage labor intensive sectors. However, the increase in the supply of unskilled labor migrants can have a positive impact on the output level of the country in case of a fully flexible capital (Dustmann et al, 2008).

The impact of immigration on commodity prices and inflation is one of the issues often examined in the literature. Ruiz and Vargas-Silva (2012), in their theoretical work related to the economics of forced migration, emphasize the necessity to study the effects of migration on prices together with. They say that parameters such as the different preferences of migrants and native people, their budgets and the amount of the aid can have different effects on aid-related and non-aid food prices. Analyzing the impacts on prices and wealth of the great immigration from Burundi and Rwanda to Tanzania in 1993-1994, Garcia and Saah (2008) conclude that the migration caused a price increase in certain groups of agricultural goods. In the same study, the local population's wealth increased in rural areas but decreased in urban areas. People in rural areas are benefiting from a surplus by selling agricultural products at a high price.

In another important study by Lach (2007), it is concluded that due to the high income elasticity of demand of refugees who moved from the Soviet Union to Israel in the 1990s, Israel experienced price declines in certain product classes.

Maystadt and Verwimp (2009) with a survey they did in Tanzania in 2008 examined the effects of forced migration from Burundi in 1993 and Rwanda in 1994. According to their findings, in contrast to expectations the forces migration has had a positive impact on the wealth of the native population. In the migration receiving regions while agricultural workers complained from competition and increasing food prices and self-employed farmers benefited from cheap labor, businesses boomed in non-agricultural sectors. Also, there was not much change in the welfare of the self-employed tradesmen.

\section{Data and Methodology}

One of the most important issues in determining the economic impact of forced migration is data limitations. Generally, almost every study compares economic data from pre- and post-migration periods. However, statistics on immigrants are not clearly specified in the published data. The data obtained from TurkStat for the period covered in the study does not include Syrian refugees. Some researchers prefer field research and survey methods instead of indirect inference due to insufficient statistics. This study uses cross-section differencing method based on TurkStat's statistics on workforce, prices, internal migration and foreign trade. The effects of migratory movements on the above-mentioned factors are examined by comparing the differences before and after the migration in relevant regions. Workforce level of education is included in the analysis as an instrumental variable to add further details to the cross-section differencing results.

As in the case of Syrian refugees, some forced migrations can create a natural experience range. Immigrants in certain regions, as in this experience, may settle in certain cities by force of law enforcement agencies as well as by a certain kind of solidarity with their fellow countrymen. This can make it easier to find sufficient data for regional analysis. Card's (1990) study of the Cuban immigration to the US and Hunter's (1992) study of Algerian immigration to certain regions of France are two examples. Camps have been created for Syrian refugees in ten different cities in southeastern Turkey. Anatolian cities in order of density are Sanliurfa, Gaziantep, Kilis, Kahramanmaras, Hatay, Adana, Adiyaman, Osmaniye and Malatya. Level 2 data (NUTS-Level 2) from TurkStats's classification of statistical regional units is used in the study and seven regions where camps have been set up including TRC2 Şanlıurfa-Diyarbakır (SD), TRC1 Gaziantep, Adıyaman and Kilis (GAK), TR63 Hatay, Kahramanmaraş and Osmaniye (HKO), TRC3 Mardin, Batman, Şırnak and Siirt (MBSS), TR62 Adana and Mersin (AM), TR52 Konya and Karaman (KK), and TRB1 Malatya, Elazı̆̆, Bingöl and Tunceli (MEBT). Permanent migrant camps are set up in all regions included in the study except in KK. When making comparison, each region where there is camp and the remaining 19 regions where there are no camps are aggregated and called the rest of Turkey. The 2010-2012 pre-migration period annual averages and the 


\section{3-2014 post-migration period annual averages are used.}

The number of Syrians in refugee camps is updated and published at regular intervals by AFAD. The total number of refugees is announced by the UNHCR. The only explanation for the dispersion of non-refugee population in cities and regions outside the camps was made in August 2014 by the Ministry of Internal Affairs. Based on UNHCR data from April 2015, Table 7 shows the ratio of refugees to city and region populations and the estimations are made based on the August 2014 announcement.

In this study unemployment rate, unemployment rate according to education level, inflation, food and non-alcoholic beverages, clothing and footwear, actual rentals for housing, transport inflation, foreign trade and internal migration data are used. Average percentages are used in the calculation of unemployment, inflation and internal migration while export and import value per employee in USD are used in the calculation of foreign trade. When analyzing the price effect, along with general inflation and commodity inflation figures 12 basic foods including wheat flour, macaroni, poultry, milk, yoghurt, white cheese, margarine, sun-flower oil, orange, apple, lentils, and granulated sugar was included in the study.

$$
\begin{aligned}
& U_{R}=\operatorname{average}\left(\text { years }_{\text {post,pre }}\right), U_{T R}=\operatorname{average}\left(\text { years }_{\text {post,pre }}\right) \\
& \operatorname{dif}_{\text {post }}=U_{R, \text { post }}-U_{T R, \text { post }} \text { and dif } f_{\text {pre }}=U_{R, \text { pre }}-U_{T R, \text { pre }} \\
& (\text { dif-dif })_{R}=\text { dif }_{\text {post }} \text {-dif } f_{\text {pre }}
\end{aligned}
$$

When working on cross-section differencing results, regional (UR) and rest of Turkey (UTR) averages in the 2010-2012 pre-migration period and the 2013-2014 post-migration period are calculated for each variable (1). Next, regional and rest-of-Turkey differences are examined for both periods (2), and difference and difference values are found for every migration region and variable (3). In the equations $\mathrm{R}$ is the relevant region while TR is the rest of Turkey, and $\mathrm{U}$ is the relevant variable.

\section{Immigration from Syria and Its Effects on the Southeastern Anatolia Economy}

As a result of the civil war in Syria in 2010, the number of Syrian civilians having to take refuge in neighboring countries in the region reached 3.9 million by April 2015. The distribution of immigrants by country can be seen in Table 3: Turkey ranks first with 1.7 million people followed by Lebanon with 1.2 million people, Jordan with 625 thousand people, Iraq with 244 thousand people and Egypt with 144 thousand people. All the countries in the region including Turkey thought that the Syrian civil war would be short-lived and the refugees would return to their country. However, in the past five years it has increased the size of the tragedy.

As of April, the number of Syrian refugees in Turkey is 1,758,092 people, including the camps. While $54 \%$ of migrants are under the age of $18,49.2 \%$ are women. The total rate is $77 \%$ for women and children. 272 thousand of refugees are living in camps, while about 1.5 million are residing in different provinces of Turkey, especially in the Southeastern Anatolia (Table 4 \& Table 5).

Table 4. Registered syrian refugee population in Turkey

\begin{tabular}{cc}
\hline Years & Number of People \\
\hline 2011 & 8000 \\
2012 & 170912 \\
2013 & 560129 \\
2014 & 1552839 \\
$2015^{*}$ & 1758092 \\
\hline
\end{tabular}

* April 2015

Source: http://data.unhcr.org/syrianrefugees/

Table 5. Demography breakdown of syrian refugees in Turkey

\begin{tabular}{cccc}
\hline Age & Male & Female \\
\hline Overall & $50.8 \%$ & $49.2 \%$ \\
$0-4$ & $11 \%$ & $10 \%$ \\
$5-11$ & $10 \%$ & $10 \%$ \\
$12-17$ & $7 \%$ & $7 \%$ \\
$18-59$ & $21 \%$ & $21 \%$ \\
$60+$ & $2 \%$ & $2 \%$ \\
\hline
\end{tabular}

April 2015

Source: http://data.unhcr.org/syrianrefugees/ 
Table 6. Syrian refugee population in camps in Turkey

\begin{tabular}{cc}
\hline Camps & Population \\
\hline Şanlıurfa & 102545 \\
Gaziantep & 49956 \\
Kilis & 36460 \\
Kahramanmaraş & 17295 \\
Hatay & 15087 \\
Mardin & 14000 \\
Adana & 11100 \\
Adiyaman & 9883 \\
Osmaniye & 9199 \\
Malatya & 7306 \\
Total* & 272831 \\
\hline
\end{tabular}

*April 2015

Source: AFAD.

The three largest camps are in Sanliurfa, Gaziantep and Kilis. The numbers of migrants in these camps are 102 thousand, 50 thousand and 36 thousand respectively (Table 6). The latest information on the distribution of immigrants residing outside camps in the cities and regions of Turkey was given by Ministry of Internal Affairs in a statement published in the Haberturk newspaper dated August 1, 2014. The information is summarized in Table 7. According to estimates based on the Ministry's statement about the distribution of refugees in certain cities, the Gaziantep, Adiyaman and Kilis region hosts the highest number of refugees with 385 thousand people followed by Istanbul with 361 thousand people. The third most populous region is the Hatay, Kahramanmaraş and Osmaniye region with about 314 thousand people. According to the calculations in Table 7 based on the city and region populations in 2014, the maximum density of Syrian refugees occurs in Gaziantep and Adiyaman and Kilis with $14.8 \%$. It is followed by the Hatay, Kahramanmaraş and Osmaniye region with a density of $10.1 \%$ and the Şanlıurfa and Diyarbakır region with 7.7\%. Syrian immigrants often prefer these regions as these regions are closer to their country and due to the ethnic similarities. However, Istanbul is hosting the most populous Syrian immigrant population due to its economic appeal.

Table 7. Syrian refugee population and percentages by region in Turkey

\begin{tabular}{|c|c|c|c|c|c|c|}
\hline Region & $\begin{array}{c}\text { Total } \\
\text { Regional } \\
\text { Population* } \\
2014\end{array}$ & $\begin{array}{c}\text { Refugee } \\
\text { Population } \\
\text { Out of } \\
\text { Camps } \\
2014^{* *}\end{array}$ & $\begin{array}{c}\text { Refugee } \\
\text { Population } \\
\text { in Camps } \\
\text { 2014*** }\end{array}$ & $\begin{array}{c}\text { Refugee } \\
\text { Population } \\
\text { Out of } \\
\text { Camps**** } \\
\text { April } 2015\end{array}$ & $\begin{array}{c}\text { Refugee } \\
\text { Population in } \\
\text { Camps April } \\
\text { 2015*** }\end{array}$ & $\begin{array}{c}\text { Percentage } \\
\text { of Refugee } \\
\text { in Regional } \\
\text { Population } \\
2015 \\
\end{array}$ \\
\hline Gaziantep, Adıyaman, Kilis & 2616082 & 271500 & 80664 & 289593 & 96299 & $14.8 \%$ \\
\hline Hatay, Kahramanmaraş, Osmaniye & 3115681 & 246000 & 40702 & 272579 & 41581 & $10.1 \%$ \\
\hline Şanlıurfa, Diyarbakır & 3480715 & 175000 & 70827 & 166826 & 102545 & $7.7 \%$ \\
\hline Mardin, Batman, Şırnak, Siirt & 2153921 & 109700 & 8103 & 115085 & 14000 & $6.0 \%$ \\
\hline Adana, Mersin & 3892850 & 95000 & 11002 & 105054 & 11100 & $3.0 \%$ \\
\hline Konya,Karaman & 2349170 & 45075 & 0 & 49392 & 0 & $2.1 \%$ \\
\hline Malatya, Elazığ, Bingöl, Tunceli & 1690843 & 1800 & 7549 & 2938 & 7306 & $0.6 \%$ \\
\hline İstanbul & 14377018 & 330000 & 0 & 361605 & 0 & $2.5 \%$ \\
\hline Ankara & 5150072 & 30000 & 0 & 32873 & 0 & $0.6 \%$ \\
\hline Bursa,Eskişehir,Bilecik & 3809784 & 20200 & 0 & 22135 & 0 & $0.6 \%$ \\
\hline Kocaeli,Sakarya,Düzce,Bolu,Yalova & 3522353 & 16900 & 0 & 18519 & 0 & $0.5 \%$ \\
\hline Antalya,Isparta,Burdur & 2898240 & 10410 & 0 & 11407 & 0 & $0.4 \%$ \\
\hline Kayseri, Sivas, Yozgat & 2378052 & 9700 & 0 & 10629 & 0 & $0.4 \%$ \\
\hline İzmir & 4113072 & 13000 & 0 & 14245 & 0 & $0.3 \%$ \\
\hline Rest of Turkey & 22148051 & 11298 & 0 & 12380 & 0 & $0.1 \%$ \\
\hline Total & 77695904 & 1385583 & 218847 & 1485261 & 272831 & $2.3 \%$ \\
\hline \multicolumn{7}{|l|}{ * TURKSTAT } \\
\hline ** Republic & Ministry & Interior & Statement. & Habertürk & Augu & 2014 \\
\hline
\end{tabular}


Different international organizations and countries, primarily the UN, provide monetary aid and public relief to Syrian refugees. In the report dated April 2015, published by UNHCR, a total of 100 million USD in aid was provided for Syrians residing in Turkey between January and April 2015. The amount of aid collected in 3.5 years between 2012 and 2015 reaching nearly 420 million USD. The biggest contribution in total assistance was provided by UNHCR with 190 million USD. However, the need is much higher than the said amount. The Turkish government is trying to meet the needs of the Syrian refugees through its AFAD budget. In the above-mentioned 3.5 years, the budget allocated to AFAD reached 3.3 billion USD. Undoubtedly an important part of the budget was used to meet the humanitarian needs of Syrian refugees. Table 8 shows in detail the distribution of aid according to years and institutions together with AFAD's annual budget.

Table 8. International funding for syrian refugees in Turkey and AFAD allowance

\begin{tabular}{lrrrr}
\hline Organization & \multicolumn{1}{c}{2012} & \multicolumn{1}{c}{2013} & \multicolumn{1}{l}{2014} & $2015^{*}$ \\
\hline International Organization for Migration & $\$ 462240$ & $\$ 1565898$ & $\$ 1858600$ & $\$ 4943199$ \\
TURKEY & - & - & - & $\$ 37498219$ \\
UNFPA & - & $\$ 1903000$ & $\$ 308414$ & $\$ 872900$ \\
UNHCR & $\$ 2118303$ & $\$ 69633769$ & $\$ 84376385$ & $\$ 33807698$ \\
UNICEF & $\$ 406061$ & $\$ 16879923$ & $\$ 31045038$ & $\$ 5213943$ \\
WFP & & $\$ 47570929$ & $\$ 58204361$ & $\$ 16910468$ \\
WHO & & $\$ 801333$ & $\$ 2059750$ & $\$ 806951$ \\
Total Funding & $\$ 2986604$ & $\$ 138354852$ & $\$ 177852548$ & $\$ 100053378$ \\
Funded $\%$ & & $37 \%$ & $36 \%$ & $16 \%$ \\
AFAD Yearly Budget & $\$ 176273919$ & $\$ 1009192609$ & $\$ 399051128$ & $\$ 216373393$ \\
\hline
\end{tabular}

*As 24 April 2015

Source: data.unhcr.org and muhasebat.gov.tr (As 24 April 2015).

In GAK region, which hosts the most dense Syrian refugee population, has paradoxically experienced a dif-in-dif unemployment rate of $-4.15 \%$ which signals that the unemployment rate has fallen markedly. The drop in the unemployment rate has mainly occurred among the illiterate and less than high school educational level, which refers to the unskilled labor category. However, a limited increase in inflation is observed. Inflation rate has been the highest within the rental prices. As shown in Table 9, inflation rate, which was $8.61 \%$ on average in the 2010-2012 period, reached $8.65 \%$ in the $2013-2014$ period while dif-in-dif ratio was at $0.61 \%$. This rate was $6.22 \%$ in rental prices. Among the 12 basic food items shown in Table 16 prices increased for 4 items while relatively decreased in 8 items. Foreign trade surplus per capita was 336 USD in 2010-2012 but increased to 1,514 USD in the period after migration. Dif-in-dif value is calculated as 1,210 USD. The volume of foreign trade and the surplus are seen to have increased in the region after the migration. The reduction of unemployment, the increase in foreign trade and the limited increase in inflation are indicative of a revival in the economy in the GAK region after the migration. However, the rate of internal migration in the region has increased, rising from $-1.99 \%$ to $-3.02 \%$ and the dif-in-dif ratio is calculated as $1.66 \%$. The region, despite the economic recovery, has experienced an increasing rate of emigration. The local population of the region migrated to other cities as a result of the refugee situation.

Table 9. Main economic indicators and dif-in-dif figures for Gaziantep, Adiyaman, Kilis

\begin{tabular}{ccccccccc}
\hline & \multicolumn{3}{c}{$2010-2012$} & \multicolumn{5}{c}{$2013-2014$} \\
\cline { 2 - 8 } & $\begin{array}{c}\text { Rest of } \\
\text { Turkey }\end{array}$ & GAK & Difference & $\begin{array}{c}\text { Rest of } \\
\text { Turkey }\end{array}$ & GAK & Difference & Dif-in-Dif \\
\hline Unemployment \% & 9.05 & 12.77 & 3.72 & 8.08 & 7.65 & -0.43 & -4.15 \\
Illiterate & 4.93 & 7.97 & 3.04 & 4.71 & 3.25 & -1.46 & -4.49 \\
Less Than High School & 8.66 & 13.77 & 5.11 & 7.38 & 7.80 & 0.42 & -4.68 \\
High and Vocational High School & 11.89 & 12.50 & 0.61 & 10.20 & 8.85 & -1.35 & -1.96 \\
Higher Education & 10.36 & 9.60 & -0.70 & 9.79 & 7.45 & -2.20 & -1.51 \\
Inflation \% & 8.30 & 8.61 & 0.31 & 7.73 & 8.65 & 0.92 & 0.61 \\
\hline
\end{tabular}




\begin{tabular}{|c|c|c|c|c|c|c|c|}
\hline Food and Non-Alcoholic & 8.75 & 9.56 & 0.81 & 10.86 & 11.76 & 0.90 & 0.09 \\
\hline Clothing and Footwear & 5.83 & 2.12 & -3.72 & 6.69 & 7.24 & 0.55 & 4.27 \\
\hline Actual Rentals For Housing & 5.01 & 5.07 & 0.07 & 6.65 & 12.94 & 6.29 & 6.22 \\
\hline Transport & 10.23 & 9.67 & -0.56 & 5.32 & 6.23 & 0.91 & 1.47 \\
\hline $\begin{array}{l}\text { Foreign Trade Balance } \\
\text { per Employee (USD) }\end{array}$ & $-4,499$ & 336 & 4,835 & $-4,530$ & 1,514 & 6,044 & 1,210 \\
\hline Export per Employee & 6,300 & 7,754 & 1,455 & 6,637 & 9,835 & 3,198 & 1,743 \\
\hline Import per Employee & 10,798 & 7,418 & $-3,380$ & 11,167 & 8,320 & $-2,847$ & -533 \\
\hline Internal Migration $\%$ & -1.69 & -1.99 & 0.30 & -1.06 & -3.02 & 1.96 & 1.66 \\
\hline
\end{tabular}

Source: Calculated from TurkStat Statistics.

The migration in the HKO region can be said to have had a more negative impact on the economy compared with GAK. As summarized in Table 10, dif-in-dif unemployment rate in the HKO region in the aftermath of the migration has reached $2.77 \%$ which means that unemployment has increased. The rise in the unemployment rate for unskilled labor is very apparent. The unemployment rate for the illiterate was 5.03\% in the 2010-2012 period but rose to $12.60 \%$ in the $2013-2014$ period. Dif-in-dif rate was $7.79 \%$. While the inflation rate relatively decreased in the region after the migration, only transport inflation was observed in the commodities included in the study. Among the 12 basic food items shown in Table 16 prices increased for 7 items while decreased in 5 items. Similar to the GAK region, the volume of foreign trade increased in the HKO region after the migration, and the foreign trade surplus per capita decreased. The foreign trade deficit which was 3,392 USD in the HKO region before the migration went down to 3,029 USD with a 394 USD dif-in-dif. Consequently, after the migration export growth rate has been higher than the import growth rate. Furthermore, the rate of internal migration in the region has declined. Dif-in-dif ratio is calculated as $-0.83 \%$. Internal migration out of the region continued but decreased slightly after the migration.

Table 10. Main economic indicators and dif-in-dif figures for Hatay, Kahramanmaras, Osmaniye

\begin{tabular}{|c|c|c|c|c|c|c|c|}
\hline & \multicolumn{3}{|c|}{ 2010-2012 } & \multicolumn{3}{|c|}{ 2013-2014 } & \multirow[b]{2}{*}{ Dif-in-Dif } \\
\hline & $\begin{array}{l}\text { Rest of } \\
\text { Turkey }\end{array}$ & HKO & Difference & $\begin{array}{l}\text { Rest of } \\
\text { Turkey }\end{array}$ & HKO & Difference & \\
\hline Unemployment \% & 9.05 & 12.00 & 2.95 & 8.08 & 13.80 & 5.72 & 2.77 \\
\hline Illiterate & 4.93 & 5.03 & 0.10 & 4.71 & 12.60 & 7.89 & 7.79 \\
\hline Less Than High School & 8.66 & 11.73 & 3.07 & 7.38 & 13.70 & 6.32 & 3.25 \\
\hline \multicolumn{8}{|l|}{ High and Vocational High } \\
\hline School & 11.89 & 15.97 & 4.08 & 10.20 & 13.40 & 3.21 & -0.88 \\
\hline Higher Education & 10.36 & 12.57 & 2.21 & 9.79 & 15.50 & 5.71 & 3.50 \\
\hline Inflation $\%$ & 8.30 & 8.75 & 0.45 & 7.73 & 7.40 & -0.33 & -0.79 \\
\hline \multicolumn{8}{|l|}{ Food and Non-Alcoholic } \\
\hline Beverages & 8.75 & 9.03 & 0.28 & 10.86 & 10.31 & -0.55 & -0.83 \\
\hline Clothing and Footwear & 5.83 & 7.22 & 1.39 & 6.69 & 4.53 & -2.16 & -3.55 \\
\hline \multicolumn{8}{|l|}{ Actual Rentals For } \\
\hline Housing & 5.01 & 8.07 & 3.06 & 6.65 & 6.92 & 0.26 & -2.80 \\
\hline Transport & 10.23 & 10.28 & 0.05 & 5.32 & 6.02 & 0.70 & 0.65 \\
\hline $\begin{array}{l}\text { Foreign Trade Balance } \\
\text { per Employee (USD) }\end{array}$ & $-4,499$ & $-3,392$ & 1,106 & $-4,530$ & $-3,029$ & 1,501 & 394 \\
\hline Export per Employee & 6,300 & 3,045 & $-3,255$ & 6,637 & 3,729 & $-2,907$ & 347 \\
\hline Import per Employee & 10,798 & 6,437 & $-4,361$ & 11,167 & 6,759 & $-4,408$ & 47 \\
\hline Internal Migration \% & -1.69 & -5.56 & 3.87 & -1.06 & -4.10 & 3.04 & -0.83 \\
\hline
\end{tabular}

Source: Calculated from TurkStat Statistics.

Şanlıurfa and Diyarbakır are the most affected cities among the other regions in the study in terms of increased unemployment rate. The $9.47 \%$ unemployment rate in the $2010-2012$ period rose up to $17.45 \%$ after the migration with an $8.95 \%$ dif-in-dif ratio. When we look at the unemployment rates by education level, dif-in-dif 
rates are calculated at $10.26 \%$ at high and vocational high school level and $13.91 \%$ at higher education level. In other words, the increase in unemployment of skilled labor is higher. Inflation level does not show a significant change. While inflation in clothing and footwear and transport decreased, food and rent inflation saw a limited increase. Despite the decline in prices for 3 of the 12 selected basic food items, the prices for 9 items went up, which confirms the limited increase in food price inflation (Table 16). As in all other regions, SD also experienced a positive trend in trade after the migration. Foreign trade surplus per capita went from 33 USD to 260 USD with a dif-in-dif value of 259 USD. Improvement in foreign trade has been the least experienced in the $\mathrm{SD}$ region. SD is also the region where internal migration rate has increased the most compared with other regions. Internal migration rate of $-6.12 \%$ in the pre-migration period rose to $-7.38 \%$ in the post-migration period with a dif-in-dif rate of $1.89 \%$ (Table 11).

Table 11. Main economic indicators and dif-in-dif figures for Sanliurfa, Diyarbakir

\begin{tabular}{|c|c|c|c|c|c|c|c|}
\hline & \multicolumn{3}{|c|}{$2010-2012$} & \multicolumn{3}{|c|}{ 2013-2014 } & \multirow[b]{2}{*}{ Dif-in-Dif } \\
\hline & $\begin{array}{l}\text { Rest of } \\
\text { Turkey }\end{array}$ & $\mathrm{SD}$ & Difference & $\begin{array}{l}\text { Rest of } \\
\text { Turkey }\end{array}$ & SD & Difference & \\
\hline Unemployment $\%$ & 9.05 & 9.47 & 0.42 & 8.08 & 17.45 & 9.37 & 8.95 \\
\hline Illiterate & 4.93 & 7.43 & 2.50 & 4.71 & 11.05 & 6.34 & 3.84 \\
\hline Less Than High School & 8.66 & 11.07 & 2.41 & 7.38 & 19.00 & 11.62 & 9.22 \\
\hline \multicolumn{8}{|l|}{ High and Vocational High } \\
\hline School & 11.89 & 8.07 & -3.74 & 10.20 & 16.55 & 6.51 & 10.26 \\
\hline Higher Education & 10.36 & 3.83 & -6.46 & 9.79 & 17.00 & 7.35 & 13.81 \\
\hline Inflation $\%$ & 8.30 & 8.91 & 0.62 & 7.73 & 8.18 & 0.45 & -0.17 \\
\hline \multicolumn{8}{|l|}{ Food and Non-Alcoholic } \\
\hline Beverages & 8.75 & 8.32 & -0.43 & 10.86 & 10.86 & 0.00 & 0.43 \\
\hline Clothing and Footwear & 5.83 & 8.23 & 2.40 & 6.69 & 7.55 & 0.86 & -1.54 \\
\hline Actual Rentals For Housing & 5.01 & 6.51 & 1.50 & 6.65 & 8.58 & 1.92 & 0.42 \\
\hline Transport & 10.23 & 10.11 & -0.13 & 5.32 & 4.04 & -1.28 & -1.16 \\
\hline $\begin{array}{l}\text { Foreign Trade Balance } \\
\text { per Employee (USD) }\end{array}$ & $-4,499$ & 33 & 4,532 & $-4,530$ & 260 & 4,790 & 259 \\
\hline Export per Employee & 6,300 & 555 & $-5,744$ & 6,637 & 725 & $-5,912$ & -168 \\
\hline Import per Employee & 10,798 & 522 & $-10,276$ & 11,167 & 465 & $-10,702$ & 426 \\
\hline Internal Migration \% & -1.69 & -6.12 & 4.43 & -1.06 & -7.38 & 6.32 & 1.89 \\
\hline
\end{tabular}

Source: Calculated from TurkStat Statistics.

The MBSS region has been affected by the Syrian refugee crisis in all unemployment, inflation and internal migration parameters. As summarized in Table 12, while the unemployment dif-in-dif rate was $8.25 \%$, inflation dif-in-dif was $0.55 \%$ and internal migration dif-in-dif was $0.28 \%$. MBSS is one of the regions affected by increased inflation and in this case the increased inflation is reflected in the price of the 12 basic food items as prices increased in 10 items and decreased only in 2 items (white cheese and sun-flower oil) (Table 16). Unemployment is observed most in less than high school category while the highest inflation increase is observed in clothing and footwear goods. Per capita foreign trade surplus rose in the MBSS region with a dif-in-dif value of 315 USD.

Table 12. Main economic indicators and dif-in-dif figures for Mardin, Batman, Sirnak, Siirt

\begin{tabular}{cccccccc}
\hline & \multicolumn{3}{c}{$2010-2012$} & \multicolumn{5}{c}{ 2013-2014 } \\
\cline { 2 - 7 } & $\begin{array}{c}\text { Rest of } \\
\text { Turkey }\end{array}$ & MBSS & Difference & $\begin{array}{c}\text { Rest of } \\
\text { Turkey }\end{array}$ & MBSS & Difference & Dif-in-Dif \\
\hline Unemployment \% & 9.05 & 15.27 & 6.22 & 8.08 & 22.55 & 14.47 & 8.25 \\
$\quad$ Illiterate & 4.93 & 16.23 & 11.30 & 4.71 & 18.65 & 13.94 & 2.64 \\
Less Than High School & 8.66 & 16.57 & 7.91 & 7.38 & 25.70 & 18.32 & 10.42 \\
High and Vocational High & & & & & & & \\
$\quad$ School & 11.89 & 15.20 & 3.31 & 10.20 & 17.80 & 7.61 & 4.29 \\
Higher Education & 10.36 & 9.10 & -1.26 & 9.79 & 17.95 & 8.16 & 9.42 \\
\hline
\end{tabular}




\begin{tabular}{|c|c|c|c|c|c|c|c|}
\hline Inflation $\%$ & 8.30 & 7.29 & -1.00 & 7.73 & 7.28 & -0.45 & 0.55 \\
\hline \multicolumn{8}{|l|}{ Food and Non-Alcoholic } \\
\hline Beverages & 8.75 & 7.36 & -1.39 & 10.86 & 10.17 & -0.69 & 0.70 \\
\hline Clothing and Footwear & 5.83 & 2.53 & -3.31 & 6.69 & 5.18 & -1.51 & 1.79 \\
\hline \multicolumn{8}{|l|}{ Actual Rentals For } \\
\hline Housing & 5.01 & 7.69 & 2.68 & 6.65 & 8.75 & 2.10 & -0.58 \\
\hline Transport & 10.23 & 10.28 & 0.05 & 5.32 & 6.02 & 0.70 & 0.65 \\
\hline $\begin{array}{l}\text { Foreign Trade Balance } \\
\text { per Employee (USD) }\end{array}$ & $-4,499$ & 4,161 & 8,660 & $-4,530$ & 4,444 & 8,974 & 315 \\
\hline Export per Employee & 6,300 & 4,744 & $-1,556$ & 6,637 & 5,247 & $-1,390$ & 166 \\
\hline Import per Employee & 10,798 & 583 & $-10,216$ & 11,167 & 803 & $-10,364$ & 149 \\
\hline Internal Migration $\%$ & -1.69 & -7.41 & 5.72 & -1.06 & -7.06 & 6.00 & 0.28 \\
\hline
\end{tabular}

Source: Calculated from TurkStat Statistics.

Compared with other regions in terms of its local population the AM region received the smallest number of refugees. So the economic effects are even more limited here. As can be seen in Table 13, a limited increase in unemployment (dif-in-dif value $0.05 \%$ ) and a slight decrease in the inflation rate were experienced, and internal migration rate is calculated to have a $0.55 \%$ dif-in-dif value. When we look at the prices of the 12 commodities in Adana and Mersin region, we can see that the prices rose for 7 items and fell for 5 items (Table 16). The foreign trade deficit of -782 USD per employee prior to migration declined to -274 USD in the 2013-2014 period, with a dif-in-dif value of 540 USD.

Table 13. Main economic indicators and dif-in-dif figures for Adana, Mersin

\begin{tabular}{|c|c|c|c|c|c|c|c|}
\hline & \multicolumn{3}{|c|}{$2010-2012$} & \multicolumn{3}{|c|}{ 2013-2014 } & \multirow[b]{2}{*}{ Dif-in-Dif } \\
\hline & $\begin{array}{l}\text { Rest of } \\
\text { Turkey }\end{array}$ & $\mathrm{AM}$ & Difference & $\begin{array}{l}\text { Rest of } \\
\text { Turkey }\end{array}$ & $\mathrm{AM}$ & Difference & \\
\hline Unemployment $\%$ & 9.05 & 12.67 & 3.62 & 8.08 & 11.75 & 3.67 & 0.05 \\
\hline Illiterate & 4.93 & 9.37 & 4.44 & 4.71 & 7.15 & 2.44 & -1.99 \\
\hline Less Than High School & 8.66 & 11.17 & 2.51 & 7.38 & 10.15 & 2.77 & 0.27 \\
\hline \multicolumn{8}{|l|}{ High and Vocational High } \\
\hline School & 11.89 & 17.33 & 5.45 & 10.20 & 15.40 & 5.21 & -0.24 \\
\hline Higher Education & 10.36 & 12.60 & 2.24 & 9.79 & 13.45 & 3.66 & 1.42 \\
\hline Inflation $\%$ & 8.30 & 8.79 & 0.49 & 7.73 & 7.46 & -0.27 & -0.76 \\
\hline \multicolumn{8}{|l|}{ Food and Non-Alcoholic } \\
\hline Beverages & 8.75 & 9.75 & 1.00 & 10.86 & 9.95 & -0.91 & -1.91 \\
\hline Clothing and Footwear & 5.83 & 5.70 & -0.13 & 6.69 & 7.98 & 1.29 & 1.42 \\
\hline Actual Rentals For Housing & 5.01 & 7.04 & 2.03 & 6.65 & 6.86 & 0.21 & -1.83 \\
\hline Transport & 10.23 & 10.86 & 0.63 & 5.32 & 5.83 & 0.50 & -0.12 \\
\hline $\begin{array}{l}\text { Foreign Trade Balance } \\
\text { per Employee (USD) }\end{array}$ & $-4,499$ & -782 & 3,717 & $-4,530$ & -274 & 4,256 & 540 \\
\hline Export per Employee & 6,300 & 2,442 & $-3,858$ & 6,637 & 2,867 & $-3,770$ & 88 \\
\hline Import per Employee & 10,798 & 3,224 & $-7,574$ & 11,167 & 3,141 & $-8,026$ & 452 \\
\hline Internal Migration \% & -1.69 & -3.60 & 1.90 & -1.06 & -3.51 & 2.45 & 0.55 \\
\hline
\end{tabular}

Source: Calculated from TurkStat Statistics.

KK region hosts Syrian refugees of about $2.4 \%$ of its population although there are no camps in the province. Apart from increased internal migration (dif-in-dif rate $0.22 \%$ ), significant disadvantages of migration are observed on unemployment, prices and foreign trade as can be seen in Table 14. Dif-in-dif rate is $-0.98 \%$ for unemployment and $-0.47 \%$ for inflation. The foreign trade surplus of 4,607 USD per capita in the 2010-2012 period went up to 4,831 USD with a dif-in-dif value of 222 USD. When the pre- and post-migration periods are compared in the Konya and Karaman region and in the rest of Turkey, it can be seen that prices for 5 food items increased and the prices for 7 items decreased (Table 16). Inflation results show a parallel finding. In particular, the fact that the increase in exports per employee is higher than that of imports has been the most important determinant of this increase. 
Table 14. Main economic indicators and dif-in-dif figures for Konya, Karaman

\begin{tabular}{|c|c|c|c|c|c|c|c|}
\hline & \multicolumn{3}{|c|}{ 2010-2012 } & \multicolumn{3}{|c|}{ 2013-2014 } & \multirow[b]{2}{*}{ Dif-in-Dif } \\
\hline & $\begin{array}{l}\text { Rest of } \\
\text { Turkey }\end{array}$ & KK & Difference & $\begin{array}{l}\text { Rest of } \\
\text { Turkey }\end{array}$ & KK & Difference & \\
\hline Unemployment $\%$ & 9.05 & 7.10 & -1.95 & 8.08 & 5.15 & -2.93 & -0.98 \\
\hline Illiterate & 4.93 & 3.03 & -1.90 & 4.71 & 2.35 & -2.36 & -0.46 \\
\hline Less Than High School & 8.66 & 6.13 & -2.53 & 7.38 & 4.40 & -2.98 & -0.45 \\
\hline \multicolumn{8}{|l|}{ High and Vocational High } \\
\hline School & 11.89 & 10.30 & -1.59 & 10.20 & 6.85 & -3.35 & -1.76 \\
\hline Higher Education & 10.36 & 9.03 & -1.33 & 9.79 & 6.90 & -2.89 & -1.56 \\
\hline Inflation $\%$ & 8.30 & 8.43 & 0.13 & 7.73 & 7.39 & -0.34 & -0.47 \\
\hline \multicolumn{8}{|l|}{ Food and Non-Alcoholic } \\
\hline Beverages & 8.75 & 10.04 & 1.29 & 10.86 & 10.67 & -0.19 & -1.48 \\
\hline Clothing and Footwear & 5.83 & 2.26 & -3.57 & 6.69 & 4.60 & -2.10 & 1.48 \\
\hline Actual Rentals For Housing & 5.01 & 3.37 & -1.64 & 6.65 & 6.70 & 0.05 & 1.69 \\
\hline Transport & 10.23 & 10.58 & 0.34 & 5.32 & 4.07 & -1.26 & -1.60 \\
\hline $\begin{array}{l}\text { Foreign Trade Balance } \\
\text { per Employee (USD) }\end{array}$ & $-4,499$ & 290 & 4,788 & $-4,530$ & 480 & 5,010 & 222 \\
\hline Export per Employee & 6,300 & 1,842 & $-4,458$ & 6,637 & 2,324 & $-4,313$ & 145 \\
\hline Import per Employee & 10,798 & 1,552 & $-9,246$ & 11,167 & 1,844 & $-9,323$ & 77 \\
\hline Internal Migration \% & -1.69 & -1.58 & -0.12 & -1.06 & -1.16 & 0.10 & 0.22 \\
\hline
\end{tabular}

Source: Calculated from TurkStat Statistics.

The calculations summarized in Table 15 for the MEBT region, where the number of Syrian refugees account for $0.6 \%$ of the region's population, show that unemployment and inflation rates decreased and the rate of internal migration increased. Dif-in-dif ratio is calculated as $-1.63 \%$ for unemployment, $-0.64 \%$ for inflation and $0.27 \%$ for internal migration. When we look at Table 16 which shows the selected items, we can see that the prices increased for 6 items and decreased for the other 6 . In the foreign trade, the value has been calculated as 490 USD.

Table 15. Main economic indicators and dif-in-dif figures for Malatya, Elazig, Bingol, Tunceli

\begin{tabular}{|c|c|c|c|c|c|c|c|}
\hline & \multicolumn{3}{|c|}{$2010-2012$} & \multicolumn{3}{|c|}{ 2013-2014 } & \multirow[b]{2}{*}{ Dif-in-Dif } \\
\hline & $\begin{array}{l}\text { Rest of } \\
\text { Turkey }\end{array}$ & MEBT & Difference & $\begin{array}{l}\text { Rest of } \\
\text { Turkey }\end{array}$ & MEBT & Difference & \\
\hline Unemployment $\%$ & 9.05 & 10.20 & 1.15 & 8.08 & 7.60 & -0.48 & -1.63 \\
\hline Illiterate & 4.93 & 2.57 & -2.37 & 4.71 & 0.95 & -3.76 & -1.39 \\
\hline Less Than High School & 8.66 & 9.97 & 1.31 & 7.38 & 6.90 & -0.48 & -1.78 \\
\hline \multicolumn{8}{|l|}{ High and Vocational High } \\
\hline School & 11.89 & 13.40 & 1.51 & 10.20 & 10.40 & 0.20 & -1.31 \\
\hline Higher Education & 10.36 & 12.60 & 2.24 & 9.79 & 12.00 & 2.21 & -0.03 \\
\hline Inflation $\%$ & 8.30 & 8.79 & 0.50 & 7.73 & 7.58 & -0.14 & -0.64 \\
\hline \multicolumn{8}{|l|}{ Food and Non-Alcoholic } \\
\hline Beverages & 8.75 & 9.39 & 0.64 & 10.86 & 10.80 & -0.06 & -0.70 \\
\hline Clothing and Footwear & 5.83 & 3.88 & -1.95 & 6.69 & 7.21 & 0.52 & 2.47 \\
\hline Actual Rentals For Housing & 5.01 & 10.97 & 5.96 & 6.65 & 11.26 & 4.60 & -1.35 \\
\hline Transport & 10.23 & 10.98 & 0.75 & 5.32 & 4.26 & -1.06 & -1.81 \\
\hline $\begin{array}{l}\text { Foreign Trade Balance } \\
\text { per Employee (USD) }\end{array}$ & $-4,499$ & 332 & 4,831 & $-4,530$ & 791 & 5,321 & 490 \\
\hline Export per Employee & 6,300 & 638 & $-5,661$ & 6,637 & 982 & $-5,655$ & 6 \\
\hline Import per Employee & 10,798 & 306 & $-10,492$ & 11,167 & 191 & $-10,976$ & 484 \\
\hline Internal Migration \% & -1.69 & -4.47 & 2.78 & -1.06 & -4.11 & 3.05 & 0.27 \\
\hline
\end{tabular}

Source: Calculated from TurkStat Statistics. 
Table 16. Selected commodity prices change differences according to regions (Turkish Lira)

\begin{tabular}{lccccccc}
\hline Commodity Name & GAK & HKO & SD & MDSS & AM & KK & MEBT \\
\hline Wheat Flour & $-0,23$ & 0,05 & 0,08 & 0,23 & $-0,05$ & -0.03 & $-0,08$ \\
Macaroni & $-0,08$ & 0,18 & 0,33 & 0,17 & 0,12 & 0.14 & $-0,15$ \\
Poultry & $-0,04$ & 0,22 & $-0,50$ & 0,03 & $-0,27$ & -0.04 & $-0,04$ \\
Milk & $-0,07$ & $-0,04$ & 0,12 & 0,06 & 0,06 & -0.18 & 0,01 \\
Yoghurt & $-0,20$ & $-0,27$ & 0,01 & 0,02 & 0,02 & -0.36 & $-0,34$ \\
White Cheese & $-0,24$ & $-1,09$ & 0,86 & $-0,10$ & 0,67 & -1.21 & $-0,33$ \\
Margarine & $-0,70$ & 0,11 & $-0,48$ & 0,31 & $-0,07$ & -0.20 & 0,02 \\
Sun-flower Oil & 0,06 & 0,07 & 0,24 & $-0,10$ & 0,04 & -0.42 & $-0,14$ \\
Orange & 0,30 & 0,18 & 0,19 & 0,18 & 0,17 & 0.29 & 0,18 \\
Apple & 0,42 & 0,13 & 0,25 & 0,03 & 0,04 & 0.10 & 0,46 \\
Lentils & $-0,29$ & $-0,19$ & 0,34 & 0,31 & $-0,29$ & 0.79 & 0,31 \\
Granulated Sugar & 0,00 & $-0,01$ & $-0,07$ & 0,09 & $-0,02$ & 0.06 & 0,04 \\
Number of Price Increase & 4 & 7 & 9 & 10 & 7 & 5 & 6 \\
Number of Price Decrease & 8 & 5 & 3 & 2 & 5 & 7 & 6 \\
\hline
\end{tabular}

Source: Calculated with dif-in-dif method from TurkStat statistics.

Considered collectively, the regions in the study show parallel features in terms of some of the indicators while different results emerge for other indicators. For each region, relationship between selected indicators and the ratio of Syrian immigrants to the population are presented in the Figures 1, 2, 3. Figure 1, which shows unemployment rate and refugee-to-population ratio, reflects that there is a parallel increase between the unemployment rate and immigrant density in all regions except GAK. It can be said that Syrian refugees apply for the local population's jobs by quite possibly willing to work at lower wages.

It is not possible to say the same for inflation. A decline in inflation was observed in all regions except MBSS and GAK. Especially the HKO region, although immigrant density is approaching 10\%, has experienced the sharpest decline in prices with a dif-in-dif value of $-0.79 \%$. On the contrary, the GAK region with an immigrant density of $15 \%$, experienced the highest inflation rate with a dif-in-dif value of $0.61 \%$. Another region experiencing increased inflation, despite $6 \%$ immigrant density, is MSSS with $0.55 \%$.

In Figure 3, which summarized the relationship between internal migration rates and the density of refugees, it can be seen that internal migration increased in all regions except for the HKO region. The highest did-in-dif rate for internal migration is in SD with $1.89 \%$ followed by GAK with $1.66 \%$. Syrian refugees are causing local people to migrate to other regions. Figure 4 shows effects on foreign trade and indicates that foreign trade surplus increased in all regions without exception. GAK has the highest trade surplus in this Figure.

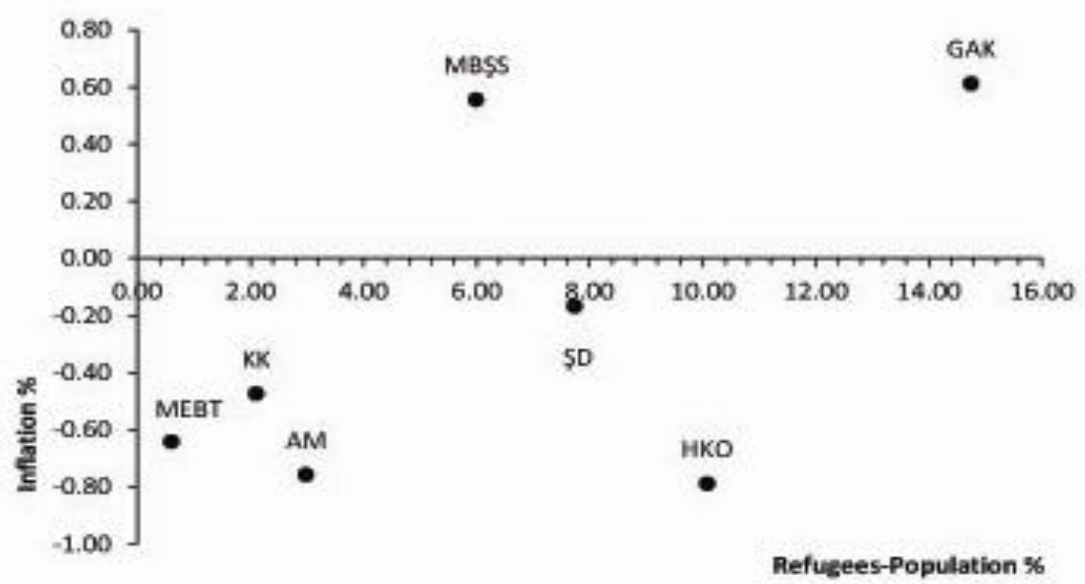

Figure 1. Unemployment and refugees-population ratio 


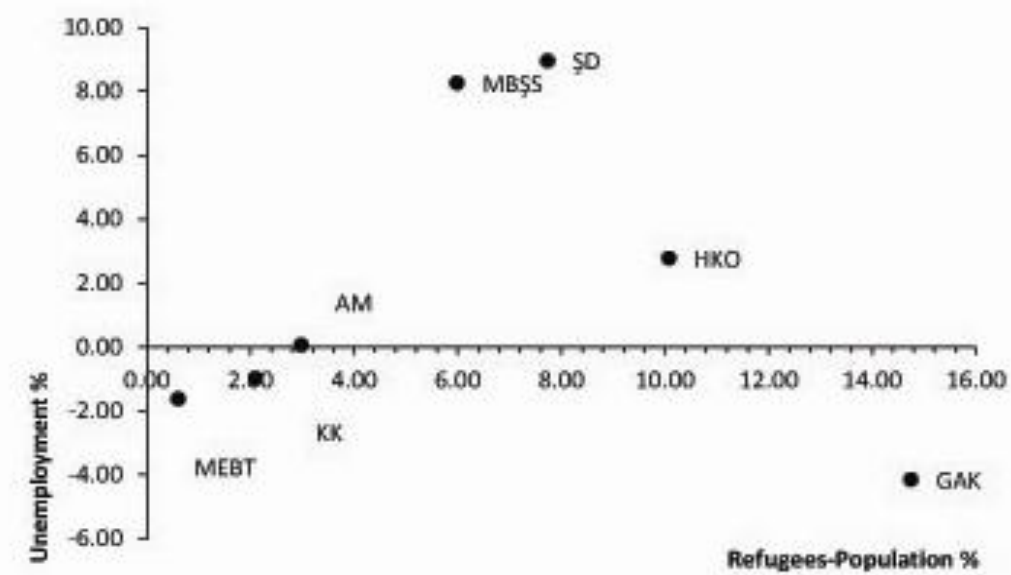

Figure 2. Inflation and refugees-population ratio

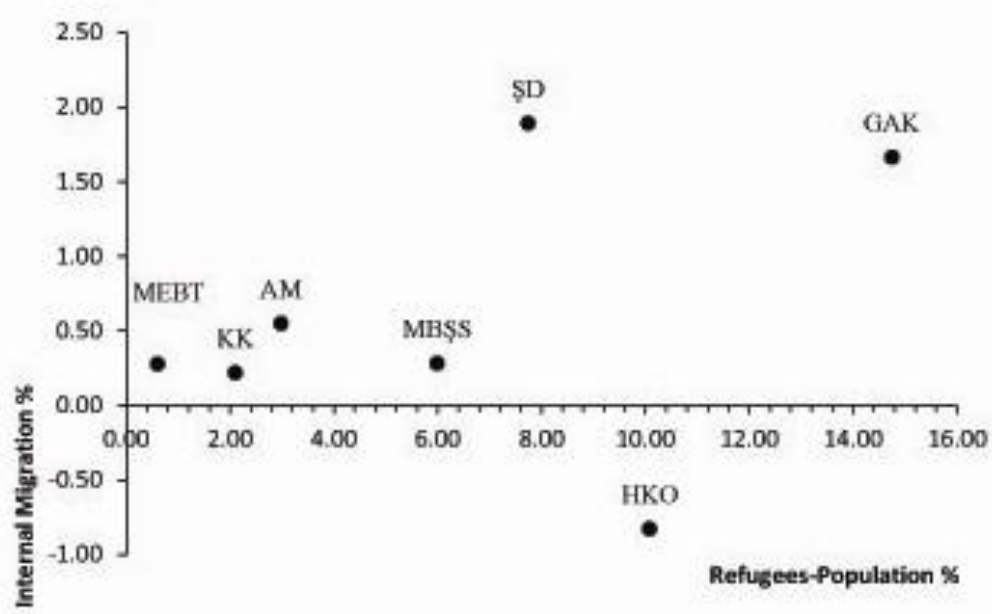

Figure 3. Internal migration and refugees-population ratio

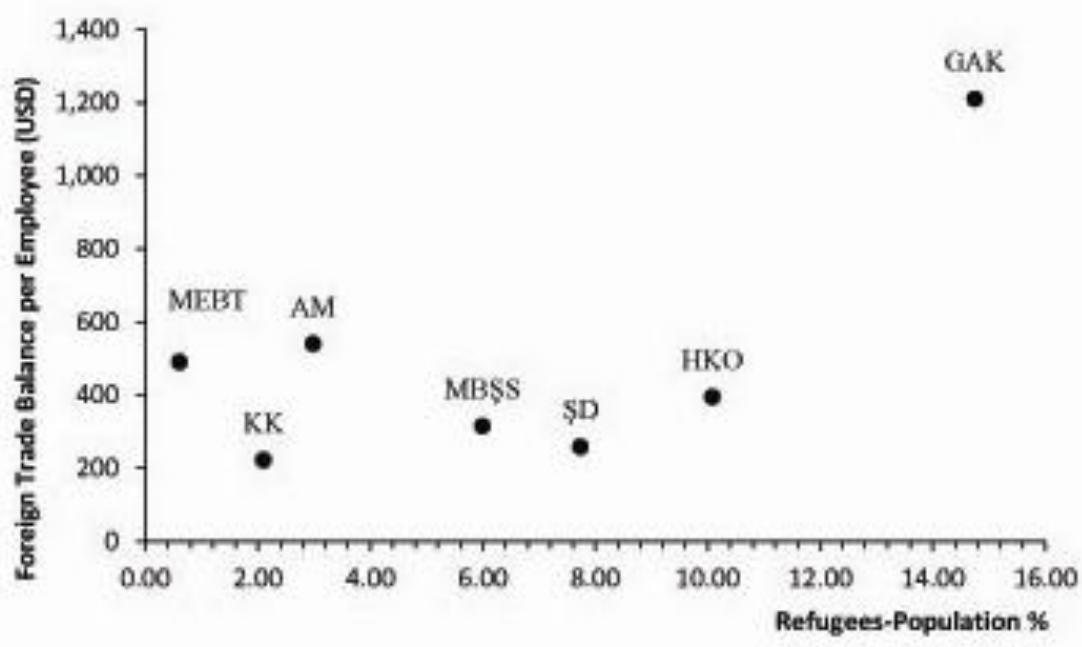

Figure 4. Foreign trade and refugees-population ratio 


\section{Conclusion}

In this study, which analyzes the Syrian refugee movement and its effects on seven different regions based on certain macroeconomic variables, the most prominent and parallel findings come from internal migration and foreign trade indicators. In all of the seven regions included in the study, internal migration rate increased and foreign trade balance improved when the Syrian refugees arrived. The improvement in trade can be said to stem from two possible reasons. The first reason is the fact that exports to northern Syria was interrupted and imports from the same region also declined with the outbreak of the civil war. The second reason is that commercial activities of Syrian refugees with other regional countries increased Turkey's exports to these regions.

Syrian refugee movement has led to a rise in the unemployment rate above the Turkey average in MEBT, KK and GAK regions. As we know that internal migration increased in regions where the unemployment rate didn't, it can be said that the decline in corporate workforce interrupted the increase in the unemployment rate. In other words, refugees compete against the local workforce, especially the unskilled workforce in these regions and deprive the natives of their jobs. Findings for inflation indicate that inflation fell in all regions except for GAK and MBSS.

The most interesting result that is also in parallel to Mundell's theory of free foreign trade comes from the GAK economy. With a population ratio of $14.8 \%$ Syrian refugees, this region experienced a fall in the unemployment rate and the highest foreign trade recovery compared with other regions. In addition, the maximum inflation rate was observed in the GAK region among other regions in the study. This can be seen as a significant sign of economic recovery. As there is no data available for gross value added and gross domestic product on regional level, it is unfortunately impossible to measure the effects of the immigration on the gross domestic product it creates.

Apart from these, taking into consideration the 1.7 million people temporarily added to Turkey's population and the 2014 growth rate, it can be easily seen that Turkish citizens are in a disadvantaged situation in terms of per capita income. Furthermore, it can also be deduced by looking at growth figures that refugees do not make a contribution to the growth of the Turkish economy. One reason for the recent rise in unemployment in Turkey can be attributed to the migration.

Regional economic effects of forced migration have been analyzed based on macro variables in this study. When sectors and markets are analyzed in detail, the results may overlap or conflict with the evaluations of the study. Therefore, sectoral studies are important for understanding micro effects. In addition, the need for a more detailed study of the effects on macroeconomic variables is obvious.

\section{References}

Akgunduz, E. A., Van Den Berg, M., \& Hassink, W. (2015). The Impact of Refugee Crises on Host Labor Markets: The Case of the Syrian Refugee Crisis in Turkey, IZA Discussion Paper, 8841.

Alix-Garcia, J., \& Saah, D. (2009). The Effect of Refugee Inflows on Host Countries: Evidence from Tanzania. The World Bank Economic Review, 24(1), 148-170. http://dx.doi.org/10.1093/wber/lhp014

Braun, S., \& Mahmoud, T. O. (2014). The Employment Effects of Immigration: Evidence from the Mass Arrival of German Expelles in Postwar Germany. The Journal of Economic History, 74(1), 69-108. http://dx.doi.org/10.1017/S0022050714000035

Card, D., Dustmann C., \& Preston, I. (2009). Immigration, Wages, and Compositional Amenities. National Bureau of Economic Research Working Paper, 15521.

Card, D. (1990). The Impact of the Mariel Baatlift on the Miami Labor Market. Industiral and Labor Relations Review, 43(2), 245-257. http://dx.doi.org/10.1177/001979399004300205

Cortes, P. (2005). The Effect of Low-skilled Immigration on US PRices: Evidence from CPI Data. Working Paper, MIT, November.

Dustmann, C., Frattini, T., \& Glitz, A. (2008). The Labour Market Impact of Immigration. CReAM Discussion Paper, No. 11/8.

Erdoğan, M. M. (2014). Türkiye'de Suriyeliler: Toplumsal Kabul ve Uyum Araştırması. Hacettepe Universitesi, Göç ve Siyaset Araştırmaları Merkezi Raporu, HUGO.

Friedberg, R. M., Hunt, J. (1995). The Impact of Immigrantson Host Country Wages, Employment and Groth. The Journal of Economic Perspective, 9(2), 23-44. http://dx.doi.org/10.1257/jep.9.2.23

Hunt, J. (1992). The Impact of the 1962 Repatriates From Algeria on the French Labor Market. Industrial and 
Labor Relations Review, 45(3), 556-572. http://dx.doi.org/10.1177/001979399204500310

Kirişçi, K. (1999). Türkiye’ye Yönelik Göç Hareketlerinin Değerlendirilmesi: Bilanço: 1923-1998, Türkiye Cumhuriyeti’nin 75 Yılına Toplu Bakış, Tarih Vakıfları Yayını, İstanbul, 1, pp: 111-121.

Kondylis, F. (2008). Conflict Displacement and Labor Market Outcomes in post-war Bosna Herzigova. HiCN Working Paper, 45.

Lach, S. (2007), Immigration and Prices. Journal of Political Economy, 115, 548-587. http://dx.doi.org/10.1086/521529

Maystadt, J., \& Verwimp, P., (2009). Winners and Losers Among a Refugee-Hosting Popultion. ECORE Discussion Paper, No. 2009/61.

Mundell, R. A. (1957). International Trade and Factor Mobility. The American Economic Review, 47(3), 321-335.

Sarmivaki, M., Uustilo, R., \& Jantti, M. (2009). Long-Term Effects of Forced Migration. IZA Working Paper No. 4003.

Tekeli, İ. (1990). Osmanlı İmparatorluğu'ndan Günümüze Nüfusun Zorunlu Yer Değiştirmesi ve İskan Sorunu. Toplum ve Bilim Dergisi, 50, 49-71.

\section{Copyrights}

Copyright for this article is retained by the author(s), with first publication rights granted to the journal.

This is an open-access article distributed under the terms and conditions of the Creative Commons Attribution license (http://creativecommons.org/licenses/by/3.0/). 